\title{
REFERENCE MODELS FOR THERMOSPHERIC NO
}

\section{A. Barh}

\author{
University of Colorado
}

Boulder, CO 80309

\begin{abstract}
Nirric oxide has been measured with an ultraviolet specrometer on the polar-orbiting satellite Solar Mesosphere Explorer (SME) for the period January 1982 to August 1986. The nirric oxide database contains densities at al! Explorer (SME) for the period Janualus latiludes soned into $5^{\circ}$.bins and at altiudes between 100 and $140 \mathrm{~km}$ soned into $3.3 \mathrm{~km}$ bins. Thetic activity. densities occur at latitudes in the auroral zones where the density vanes as a function of geomagnetic the livitic Vaniation; of a facior of 10 occur between times of intense activity and quier umes. Al 198210 a mean vilue of oxide cessity at $110 \mathrm{~km}$ viries from a mean value of $3 \times 10^{7}$ molecules/cm 3 in the low-lacitude nitric oxide densily Ax $10^{6}$ nia..... $u ! e s / \mathrm{cm}^{3}$ during solar minimum condis on high solar activity.
\end{abstract}




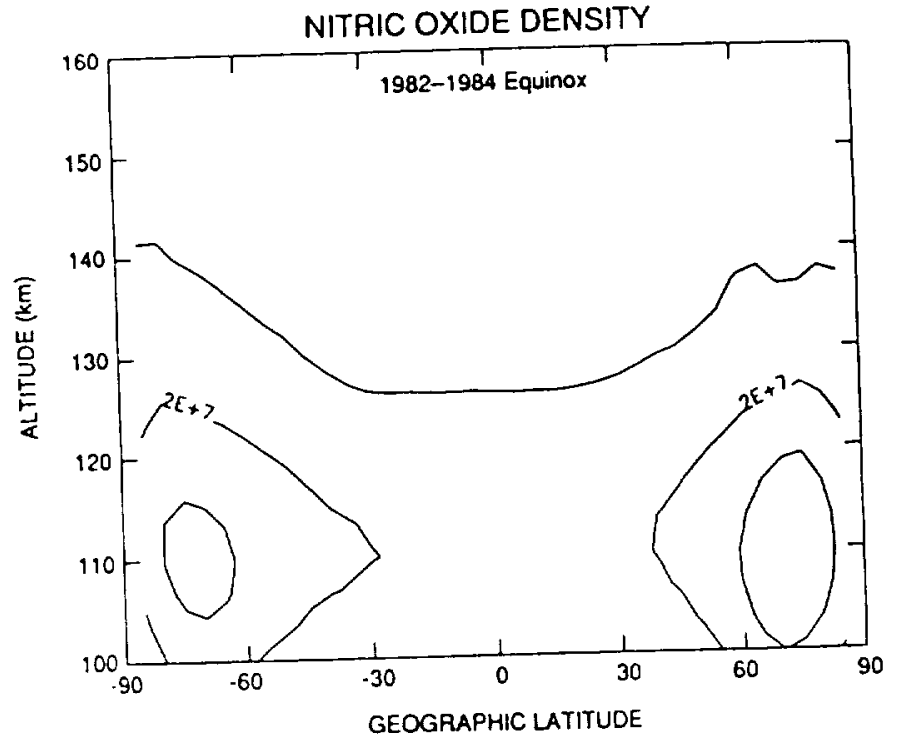

1. Nitic Figure 1. Nitric oxide densily for the 1982-1984 equinox penods as a funcdon of for the years 1982, 1983, and Observations for the periods March 7 to April 2 and Sepieniber $1010 \mathrm{Cm}^{-3}$ and the lowesi contour level is $1 \times 10^{7}$ 198.4 are averaged

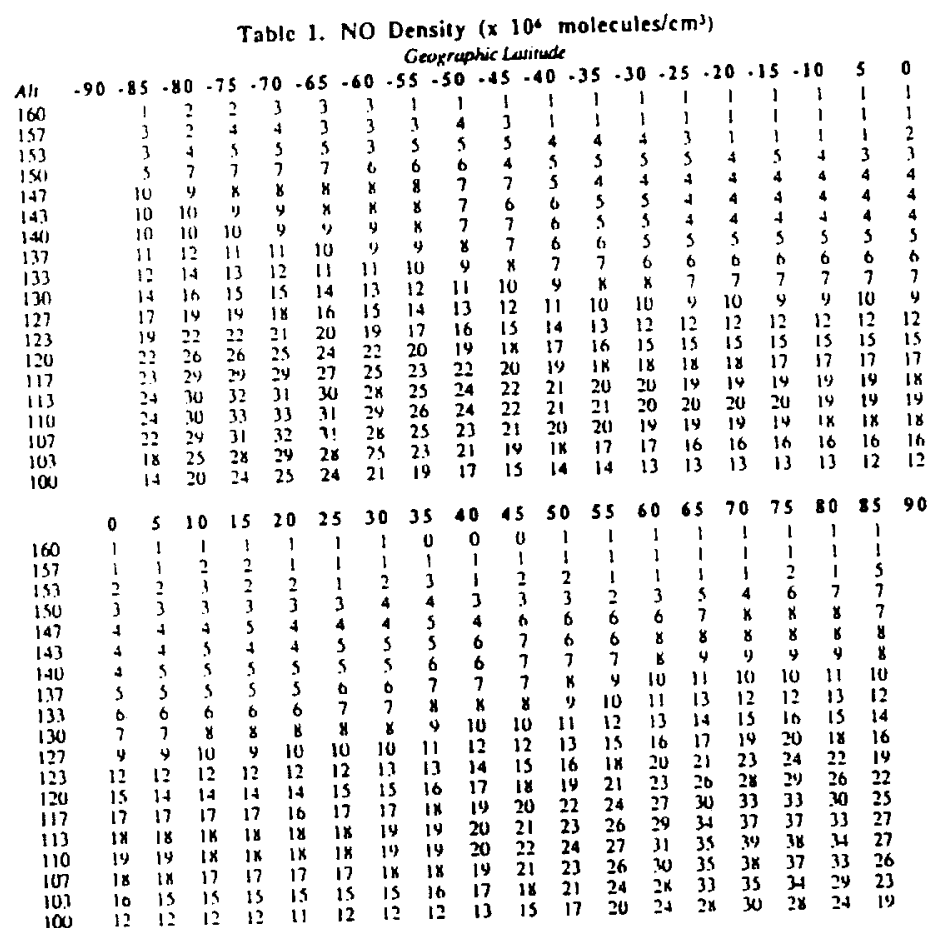

. Nirric oxide density tor the 1982-1984 equinox periods as is function of geouraphic latiude and altitude Table 1. Nienc oxide density tor the 1982.1984 equinox periods as 1 Ocrober 6 for the years 1982, 1983, and Observations for the periods $M$ arch 7 to $A$ pril 2 and Septeniber in units of $10^{\circ}$ molecules $\mathrm{cm}^{3}$ 


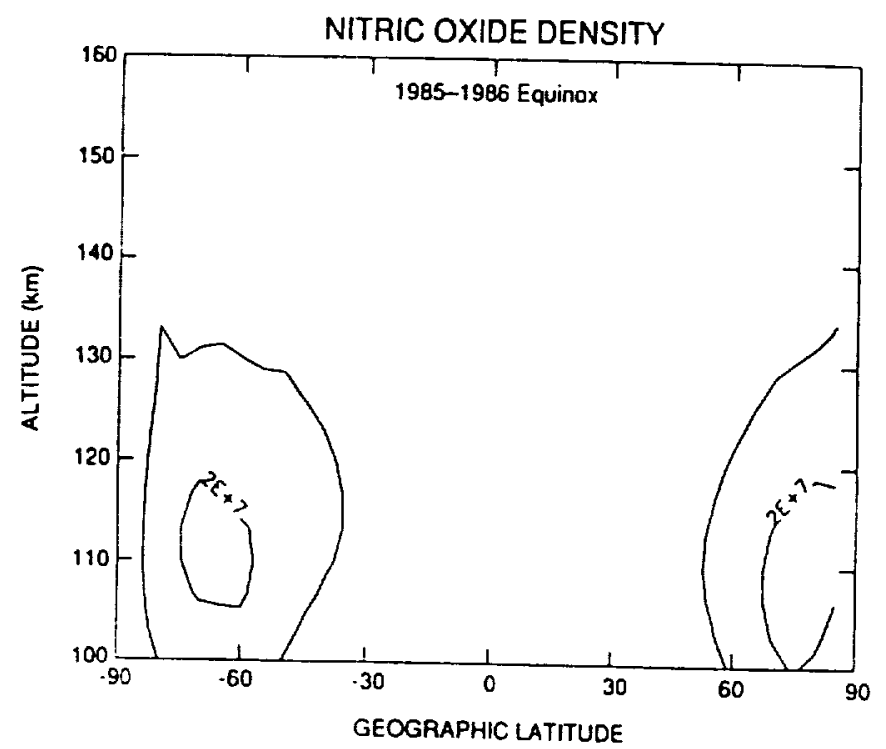

Figure 2. Nitric oxide density for the 1985-1986 equinox periods as a function of geographic latitude and alcitude. Observations for the penods March 710 April 2 of 1985 and 1986 and September 10 wo October 6 for the year 198.5 are averaged together. The contour interval is $1 \times 10^{7}$ molecules $\mathrm{cm}^{-3}$ and the lowest contour level is $1 \times 10^{7}$
molecules $\mathrm{cm}^{3}$.

Table 2. NO Density ( $x 10^{6}$ molecules $/ \mathrm{cm}^{3}$ )

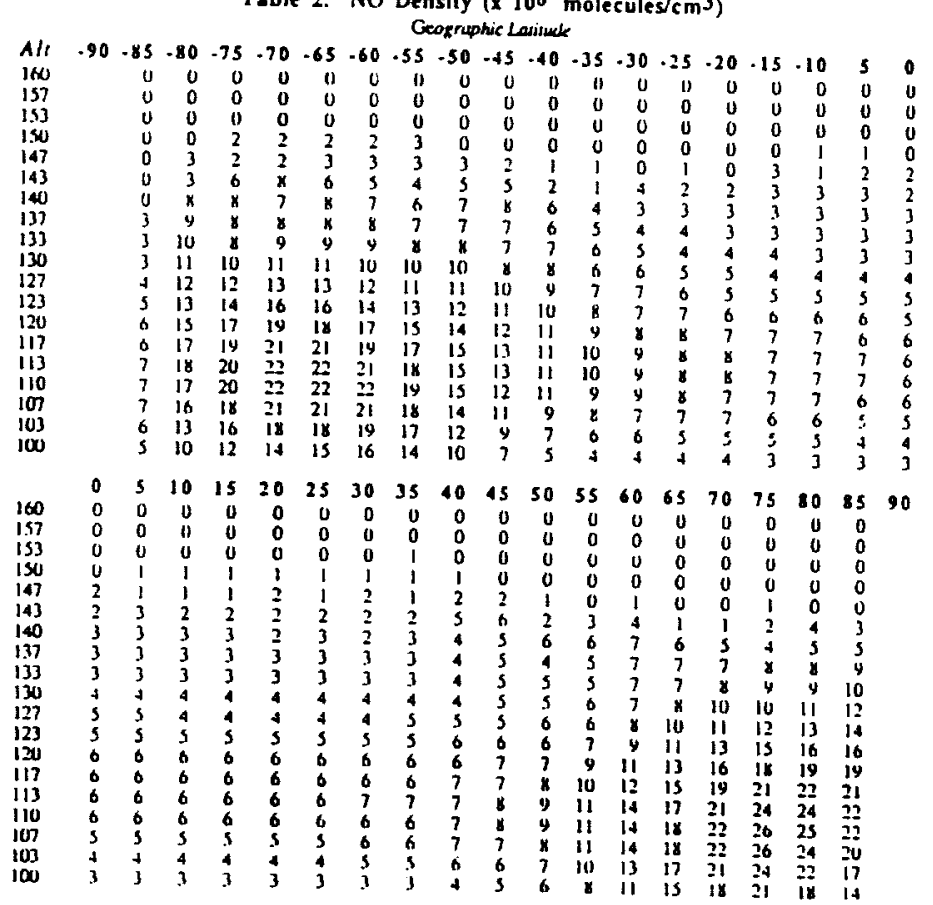

Tible 2. Nitric oxide density for the 1985-1986 equinox periods as a function of geographic latitude and altit wde. Observations for the penods March 7 to $A$ pril 2 of 1985 and 1986 and Sepienber 10 to $Q$ couber 6 for the ye:

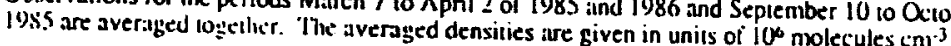




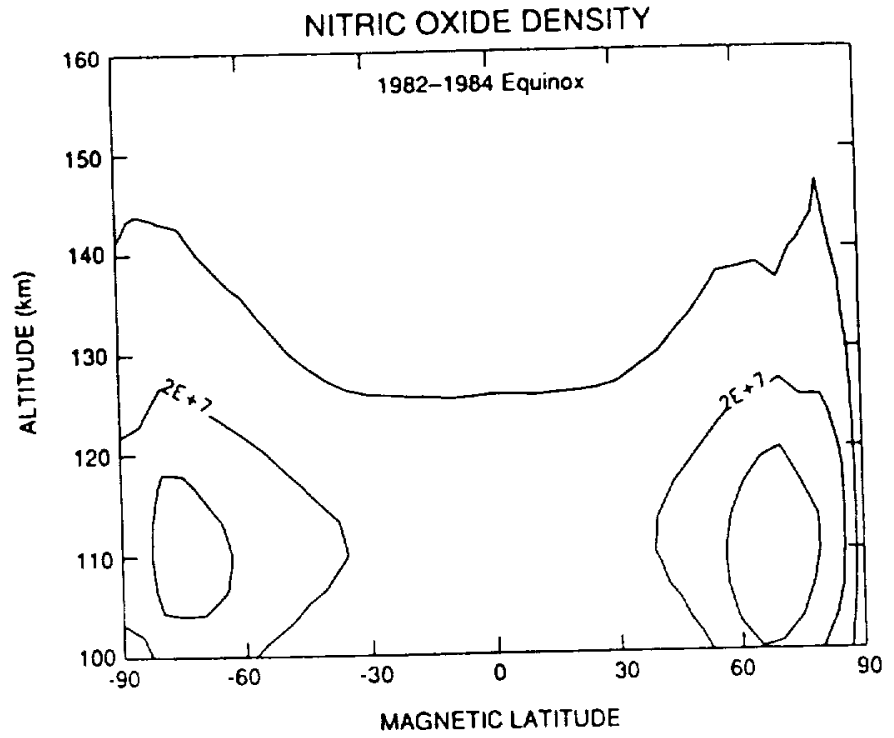

Figure 3. Nitric oxide density for the 1982-1984 equinox periods as a funcrion of geomagnetic latitude and Fire 3. Ne altilude. Observations for the periods March 7 to $\mathrm{April}$. is $1 \times 10)^{7}$ molecules $\mathrm{cm}^{3}$.

Table 3. NO Density (x $10^{\circ}$ molecules/em)

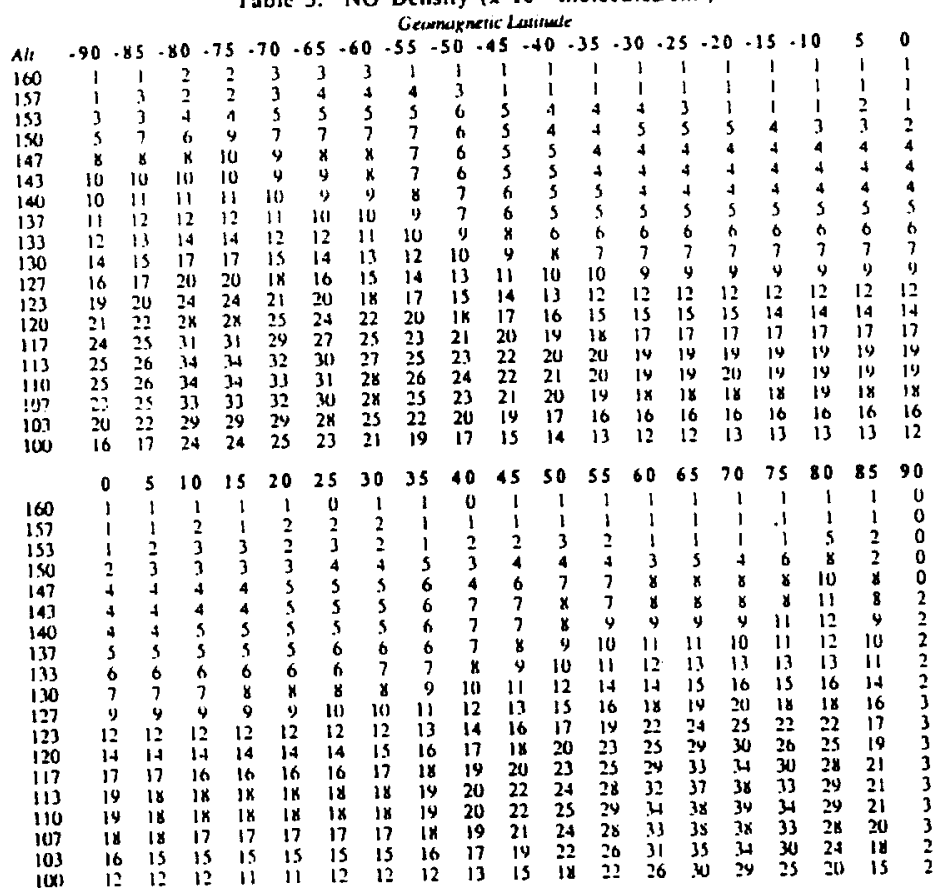

Table 3. Nirric oxide densily for the 1982-1984 equinox periods as a function of geomagnetic latude and Table 3. Nitric oxide densily for the 1982-1984 eguinox periods as a fur 10 to Oclober 6 lor the yeirs $19 \times 2$.

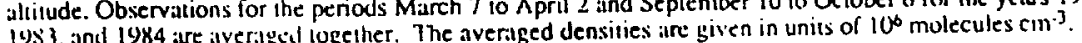




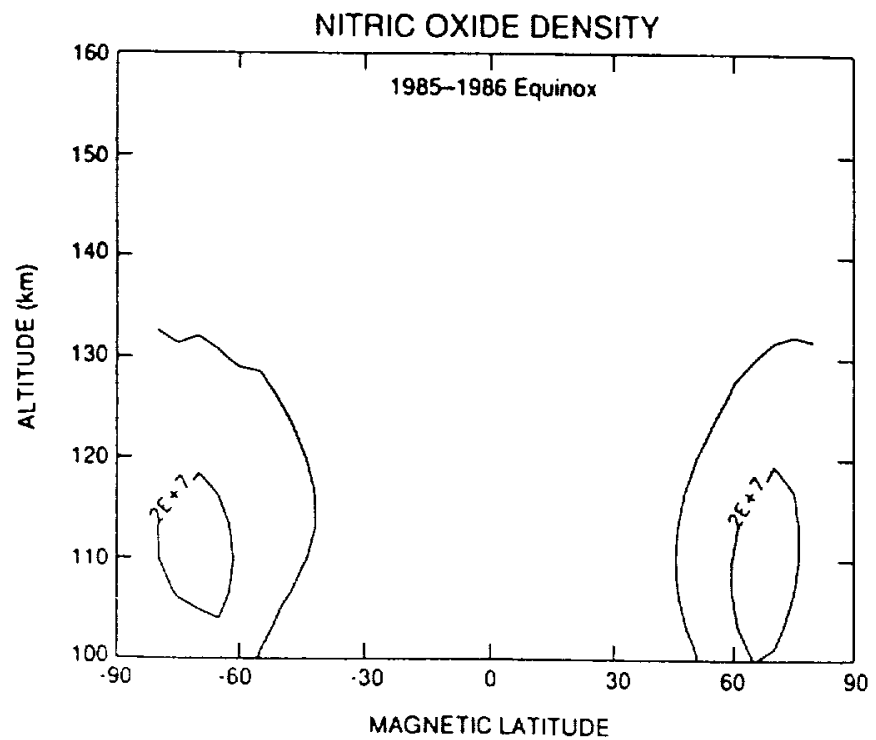

Figure 4. Nitric oxide density for the 1985-1986 equinox periods as a funcrion of geomagnecic lalitude and ultitude. Observations for the periods Miurch 7 to April 2 of 1985 and 1986 and Seplember 10 10 October 6 1985. are averaged logether. The contcur interval is $1 \times 10^{7}$ molecules $\mathrm{cm}^{-3}$ and the lowest contour level is $1 \times 10^{7}$ molecules $\mathrm{cm}^{-3}$.

Table 4. NO Density ( $\times 10^{*}$ molecules $/ \mathrm{cm}^{3}$ )

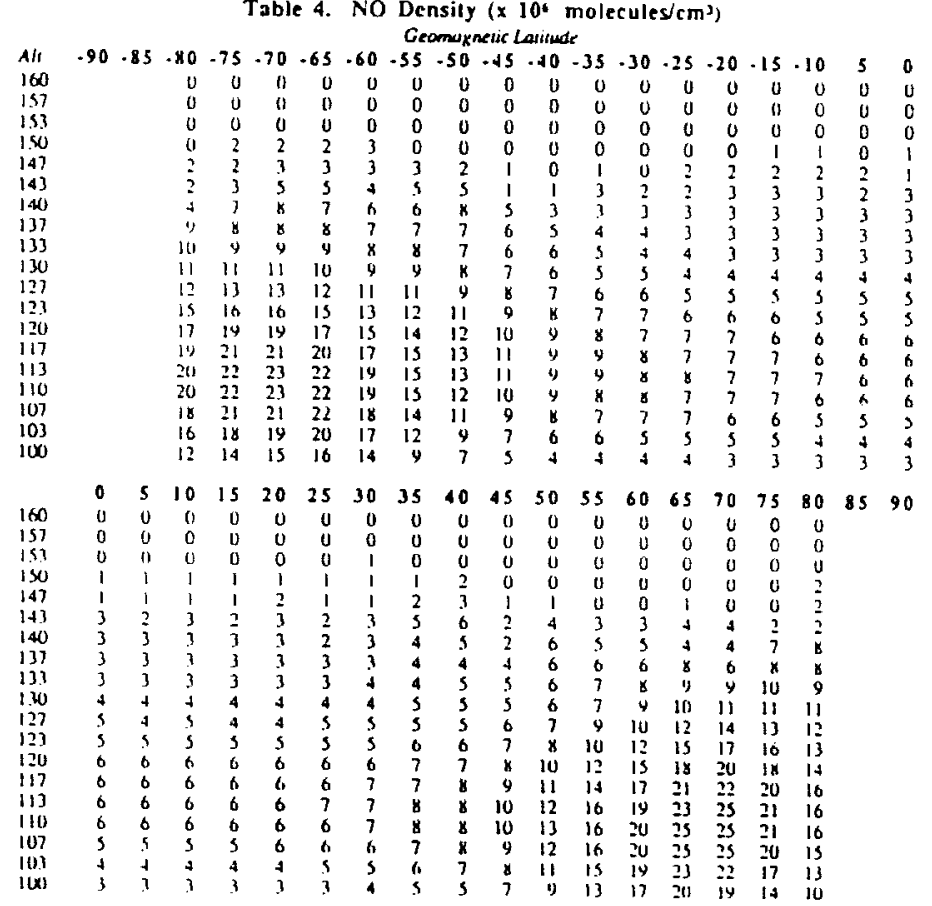

Table 4. Nivic oxide density for the 1985-1986 equinox periods as a funcion of geonagneric latitude and

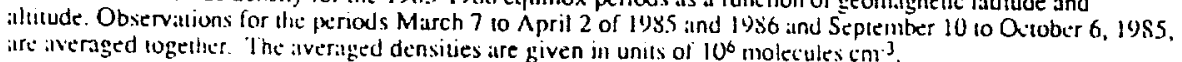




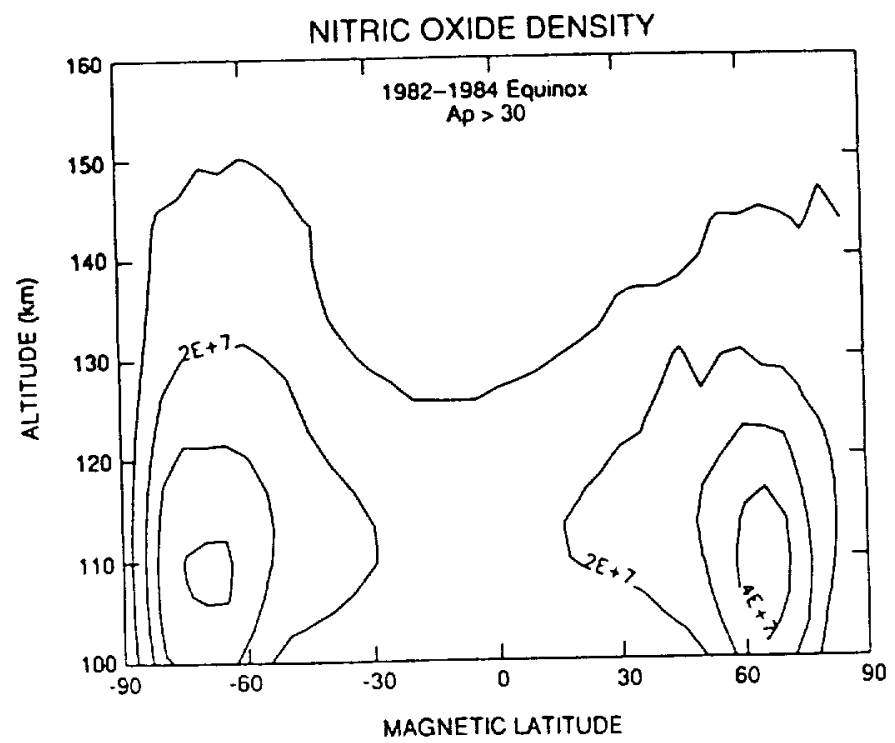

Fimure 5. Nitic oxide density for the 1982-1984 equinox periods as a function of geomagnetic latitude and Figure 5. Nitic oxide density for the 1982-10 equ periods March 710 April 2 and Seplember 10 10 October 6 altirude for days when $A_{p}>30$. Observations for the periods March for the years 1982, 1983 , and 1984 ire averaiged

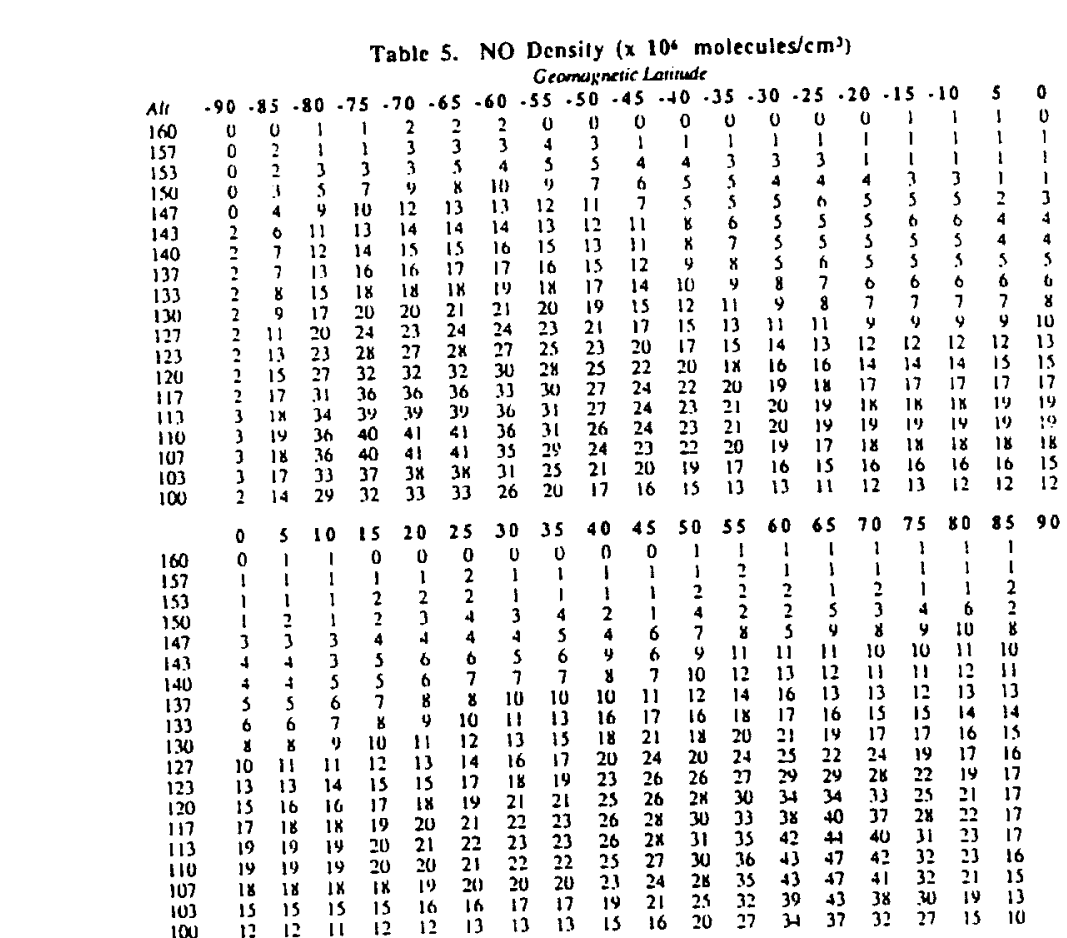

Table 5. Nitric oxide densicy for the 1982-1984 equinox periods as a function of geomagnetic liatitude and allitude for days when Ap>30. Observations for the periods March 7 to April 2 and Seplember 10 so Oelober 6 lor lilio for day's when $A_{n}>30$. Observations for the periods Mareh yciurs ! 


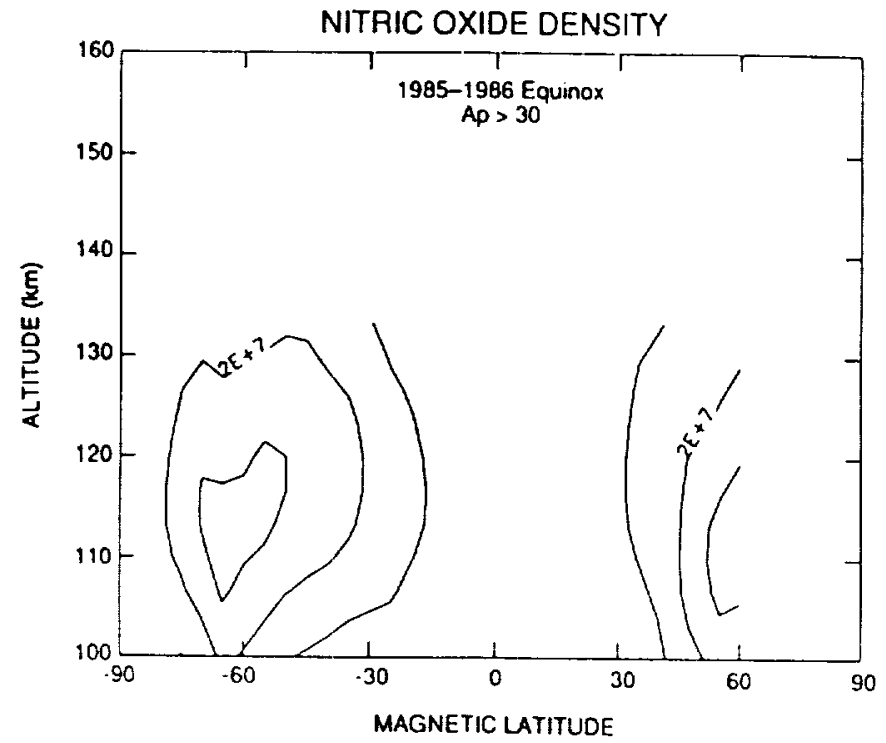

Figure 6. Nitric oxide density for the 1985-1986 equinox periods as a funcion of geomagnecic latitude and allitude for days when $\Lambda p>30$. Observations for the periods Mirch 7 10 April 2 of 1985 and 1986 and Sepiember 10 to October 6.198 .5 , are averaged together. The contous interval is $1 \times 10^{7}$ molecules $\mathrm{cm}^{-3}$ and the lowest contour level is $1 \times 10^{7}$ molecules $\mathrm{cm}^{3}$.

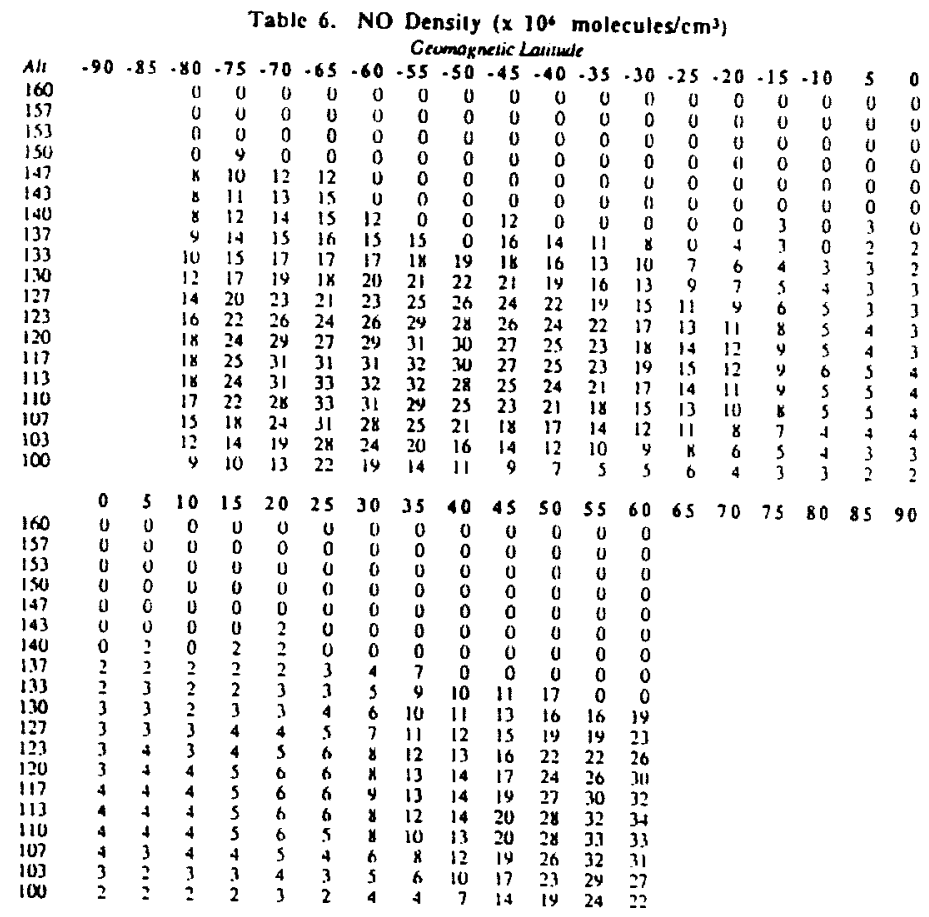

Table 6. Nitric oxide dinsity tor the 198.5-1986 equinox periods as a funclion of geonatgnetic lattude and altilude lor ditys when $A p>30$. Observations for the periods March 7 to $\wedge$ pril 2 of $19 \times 5$ and 1986 and Seplember 10 to Qituber 6,1985, are averaged together. The averaged densilies are given in units of $1 U^{4 \prime \prime}$ indecules $\mathrm{cm}^{3}$ 


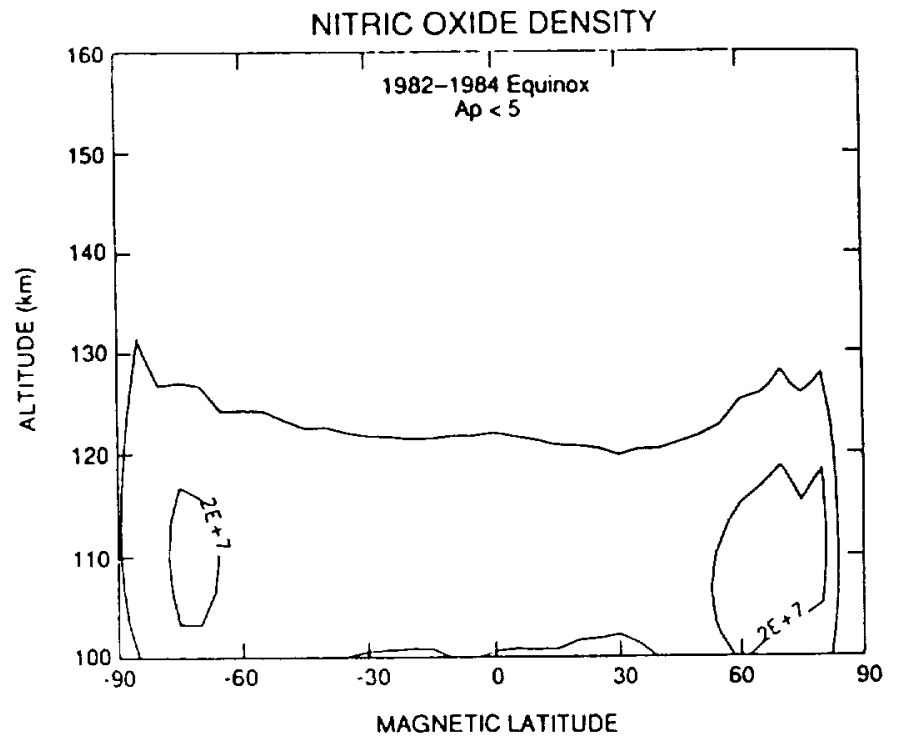

Figure 7. Nitric oxide density for the 1982-1984 equinox periods as a funcrion of geomagneric latitude and ultitude for days when Ap<5. Observations for the periods March 7 10 April 2 and Seplember 10 to October 6 for the years 1982,1983, and 1984 are averaged together. The contour interval is $1 \times 10^{7}$ molecules $\mathrm{cm}^{-3}$ and the lowest contour level is $1 \times 10^{7}$ nolecules $\mathrm{cm}^{3}$.

Table 7. NO Density (x 10* molecules $/ \mathrm{cm}^{3}$ )

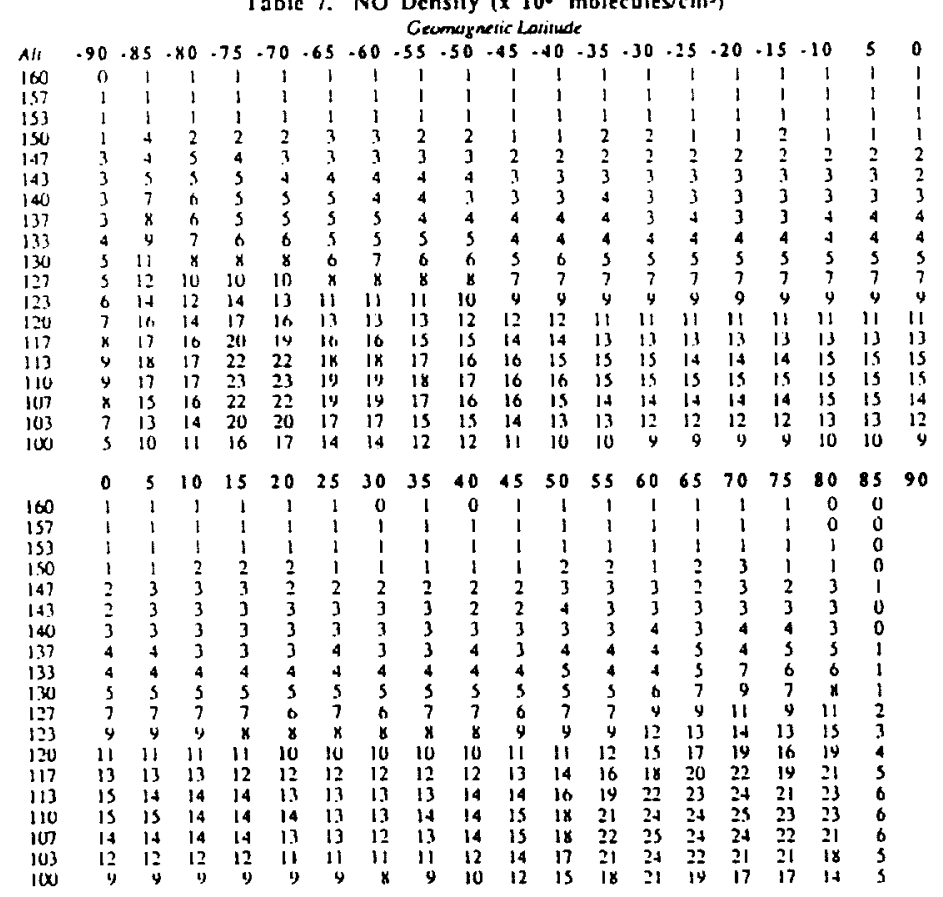

Tible 7. Nitric oxide density for the 1982-1984 equinox periods as a funcrion of geomagneric latitude itnd altitude ior diays when $A$ <is. Observialions for the periods March 7 to April 2 and Septeinber 10 to October 6 for the ycius 1982, 1985, and 19\$4 are averilged logether. The averilged densities are given in unils of $10 \%$ molecultes $\left(\mathrm{mi}^{3}\right.$. 


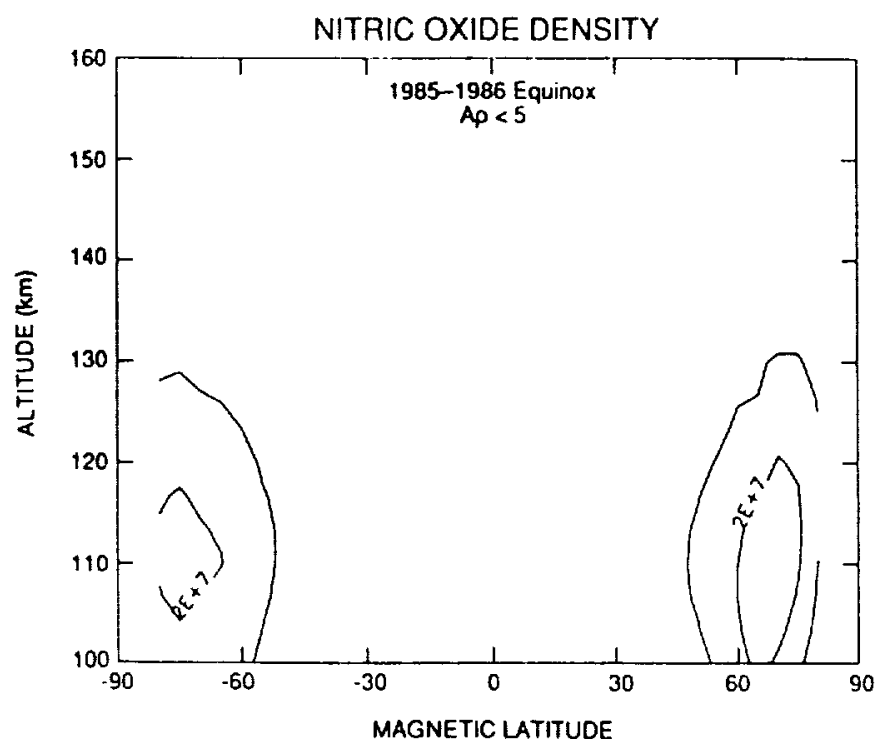

Figure 8. Nitric oxide density for the 1985-1986 equinox periods as a function of geomagne ic latitude and altitude for days when Apes. Observations for the periods March 710 April 2 of 1985 and 1986 and September 10 to October 6, 1985, ure averaged together. The contour intervial is $1 \times 10^{7}$ molecules $\mathrm{cm}^{-3}$ and the lowest contour level is $1 \times 10^{7}$ molecules $\mathrm{cm}^{3}$.

Table 8. NO Density (x 10; molecules/em')

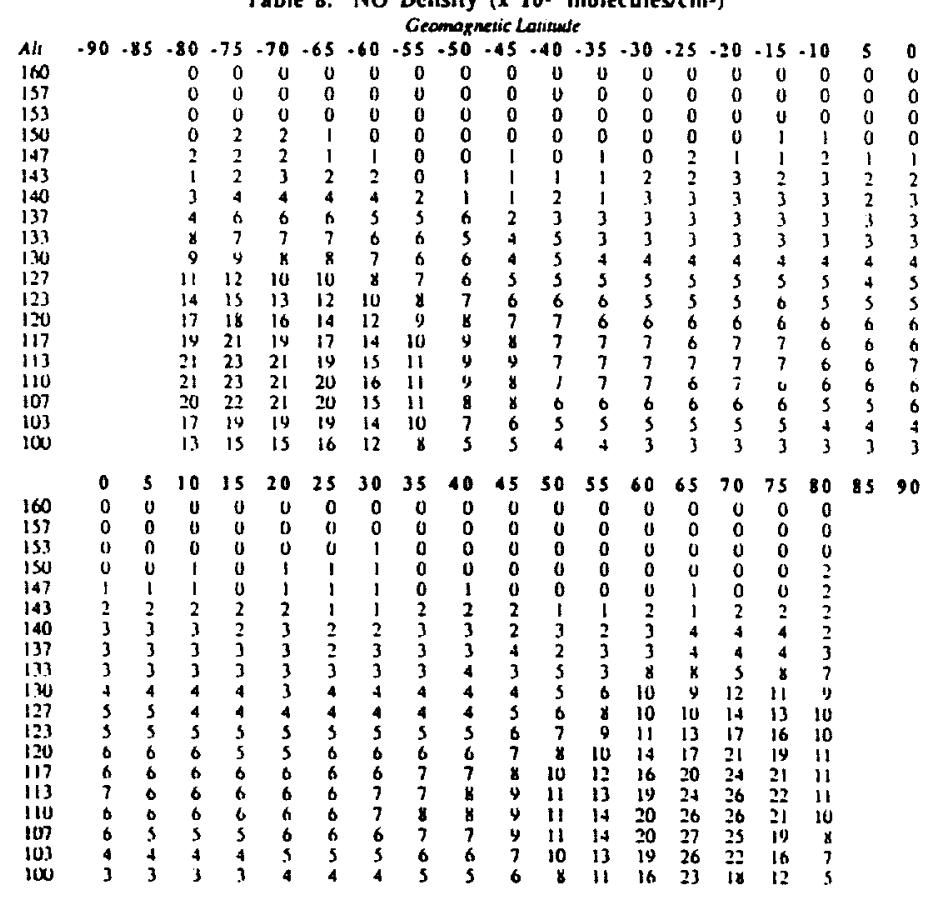

Table 8 . Nitric oxide density for the 1985-1986 equinox periods as a function of geomagneic latitude and allitude for divs when Ap<5. Observations for the periods March 7 to April 2 of 1985 and 1986 and Seplember 10 to Oe'wber 6.1985, are averiged logether. The avernged densities are given in units of $10^{6}$ molecules $\mathrm{cm}^{3}$. 


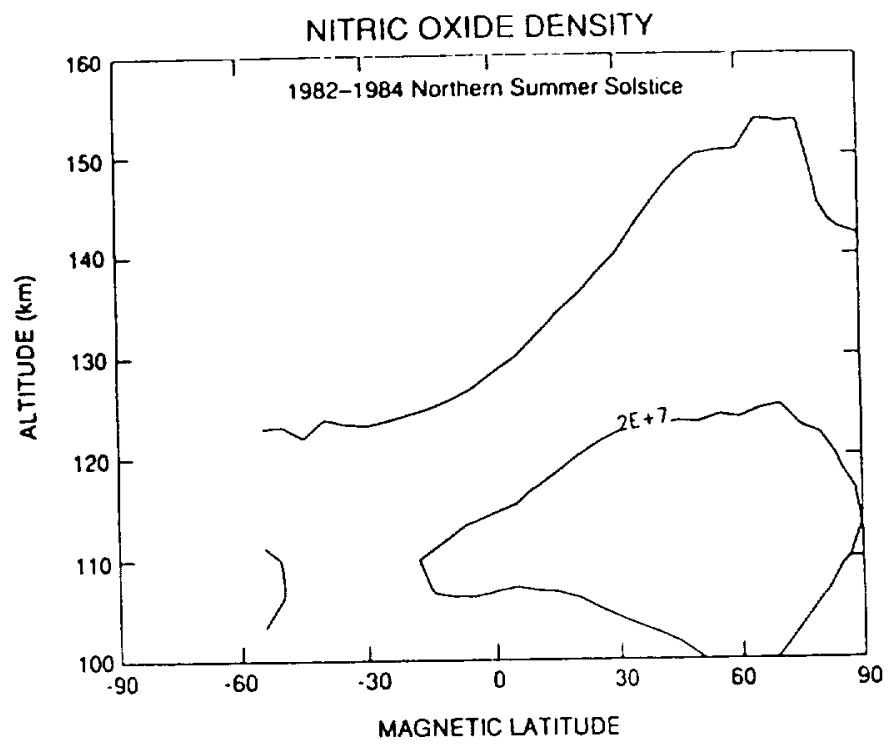

Figure 9. Nirric oxide densily for the 1982-1984 nonhern summer solstice as a funcrion of geomagnetic latifude Figure 9. Nicic oxide densily the periods June 8 to July 4 for the years 1982, 1983, and 1984 are averaged agether. The contour interval is $1 \times 10^{7}$ molecules $\mathrm{cm}^{-3}$ and the lowest coniour level is $1 \times 10^{7}$ molecules $\mathrm{cm}^{-3}$.

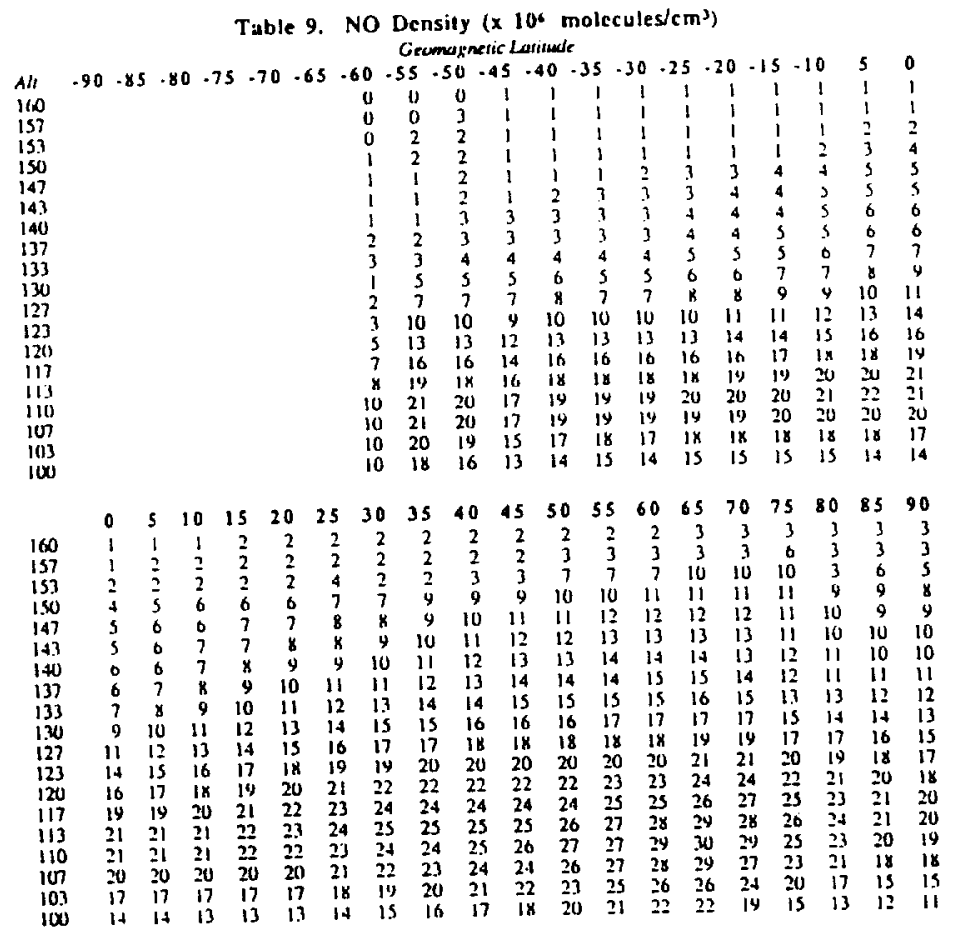

Table 9 . Niric oxide density for the 1982-1984 northern summer solstice as a function of geomagnetic hatitude Table 9. Nitnc oxide density for the 1982-1984 northern 4 for the yeirs 1982, 1983, and 19S't are averaged and altitude. Observations lor the penods Jute 8 ito July $10^{6}$ molecules $\mathrm{cm}^{-3}$. 


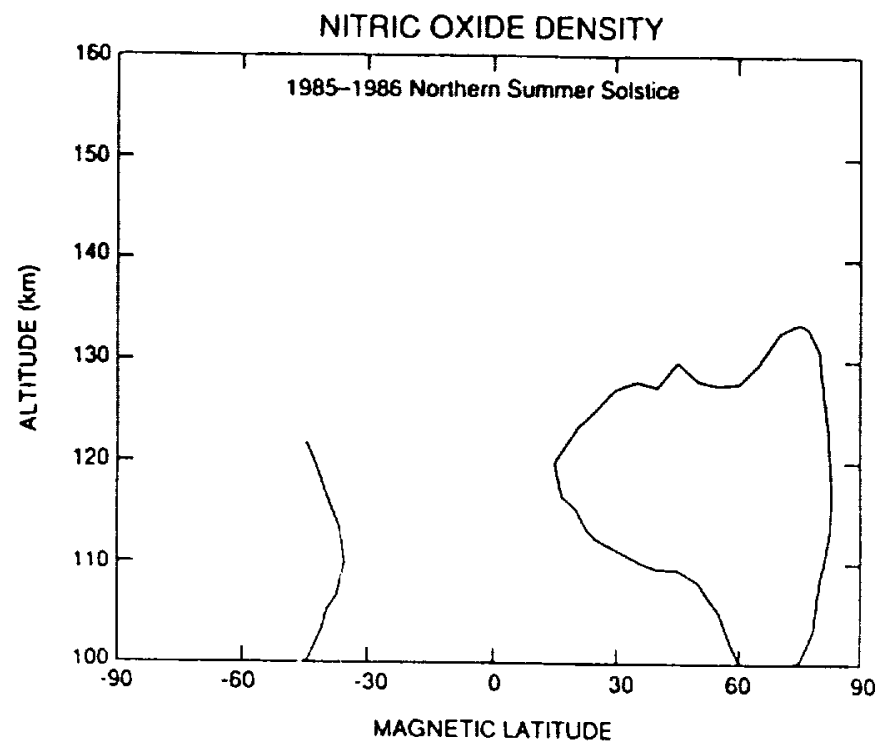

Figure 10. Nitric oxide density for the 1985-1986 nonhern summer solstice as a function of geomagnetic latitude and altitude. Observations for the periods June 8 to July 4 for the years 1985 and 1986 are averaged together. The contour interval is $1 \times 10^{7}$ molecules $\mathrm{cm}^{-3}$ and the lowest contour level is $1 \times 10^{7}$ molecules $\mathrm{cm}^{3}$.

Table 10. NO Density (x 104 molecules/(m³)

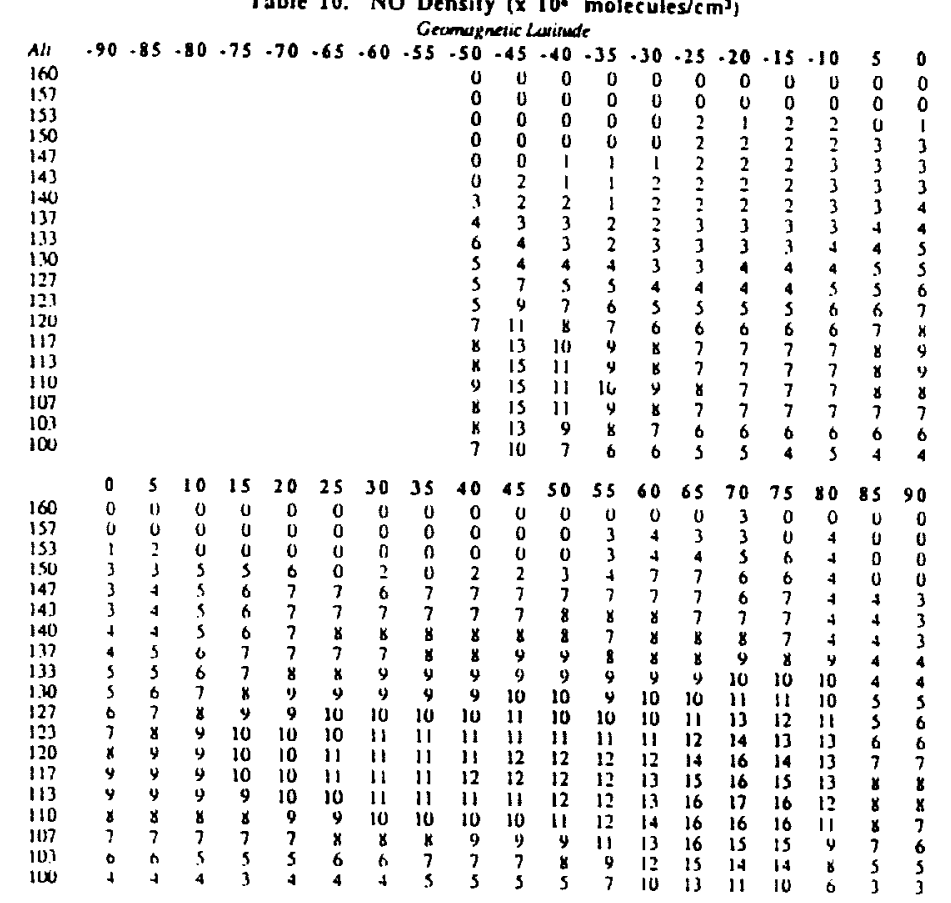

Table 10. Nitric oxide density for the 1985-1986 nonhern summer solstice as a function of keomannetic littitude and altitude. Obsen:itions for the periuds June 8 to July 4 for the years 1985 and 1486 are ilveraged together. The averiged densicies are given in units of $10^{6}$ molecules $\mathrm{cm}^{-3}$. 


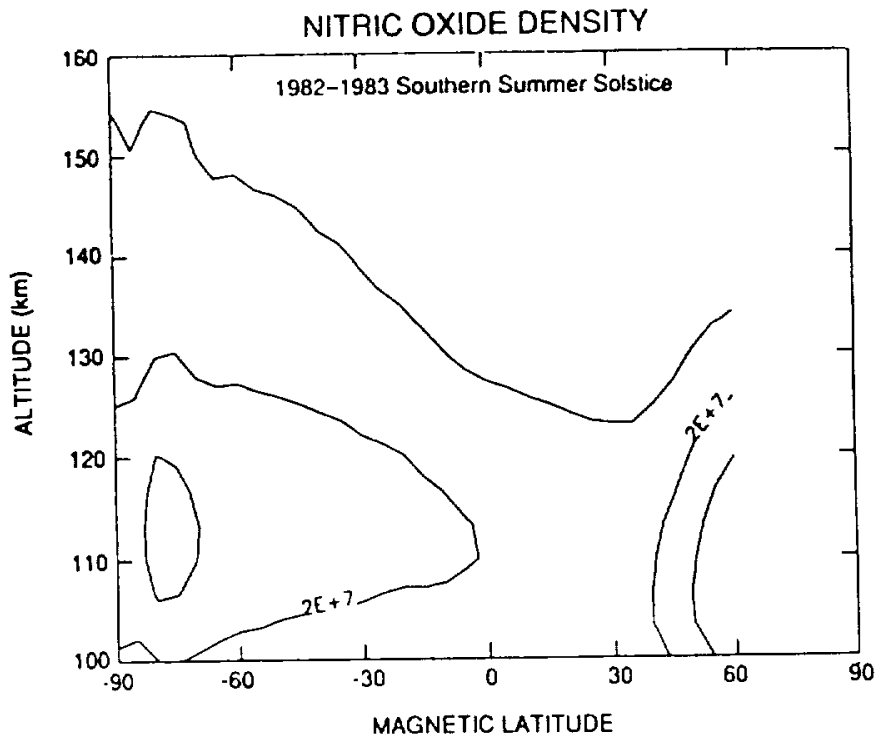

Figure 11. Nitric oxide density for the 1982-1983 southern summer solstice as a function of geomagnetic latitude and alticude. Observations for the period December 9 to January 4 for 1982 and 1983 are iveraged togecher. The contour interval is $1 \times 10^{7}$ molecules $\mathrm{cm}^{-3}$ ind the lowest contour level is $1 \times 10^{7}$ molecules $\mathrm{cm}^{3}$.

Table 11. NO Density (x 106 molecules/cm3)

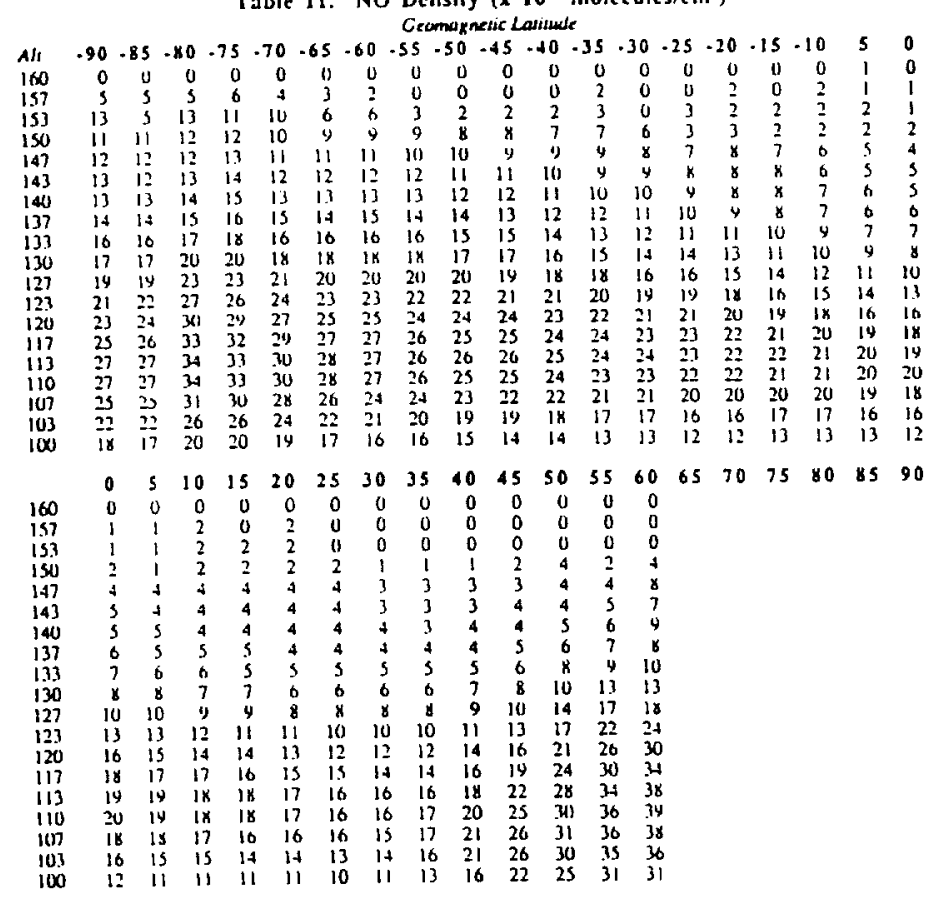

T.bble 11. Nitric oxide density for the 1982-1983 southem summer solstice as a function of geomagne uic latitude and altitude. Observallions lor the period December 1) o Jantairy 4 for 1982 and 1983 are averiged logether. The averaged densities are givell in units of $10^{6}$ molecules $\mathrm{cm}^{-3}$. 


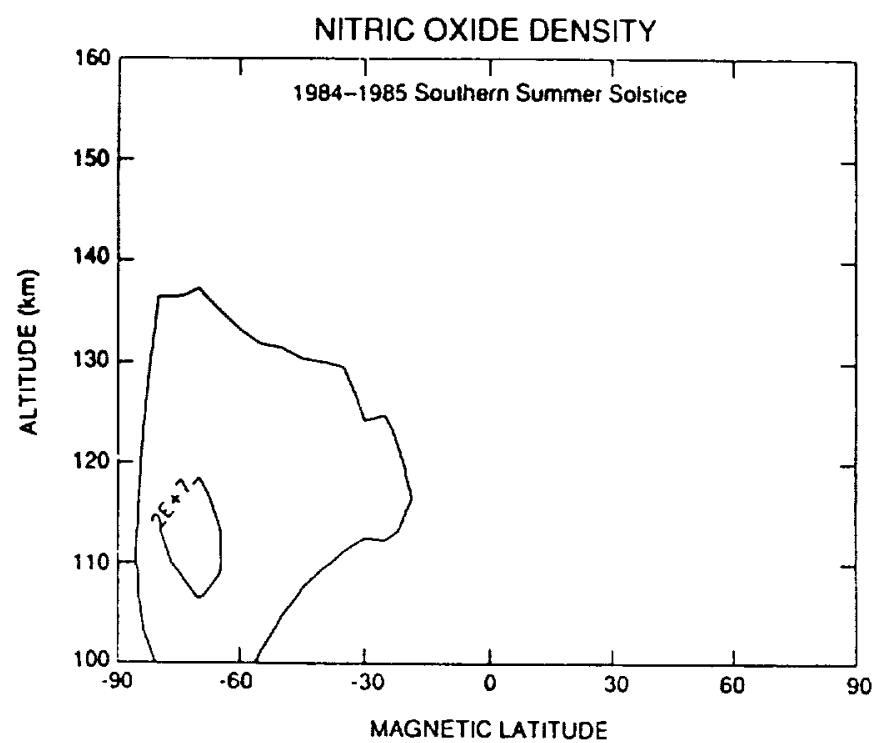

Figure 12. Nivic oxide density for the 1984-1985 nonthem summer solstice as a function of geomagnetic latitude and altitude. Observations for the periods December 9 to January 4 for the years 1984 and 1985 are averabed logether. The contour inierval is $1 \times 10^{7}$ molecules $\mathrm{cm}^{-3}$ and the lowest contour level is $1 \times 10^{7}$ molecules $\mathrm{cm}^{-3}$.

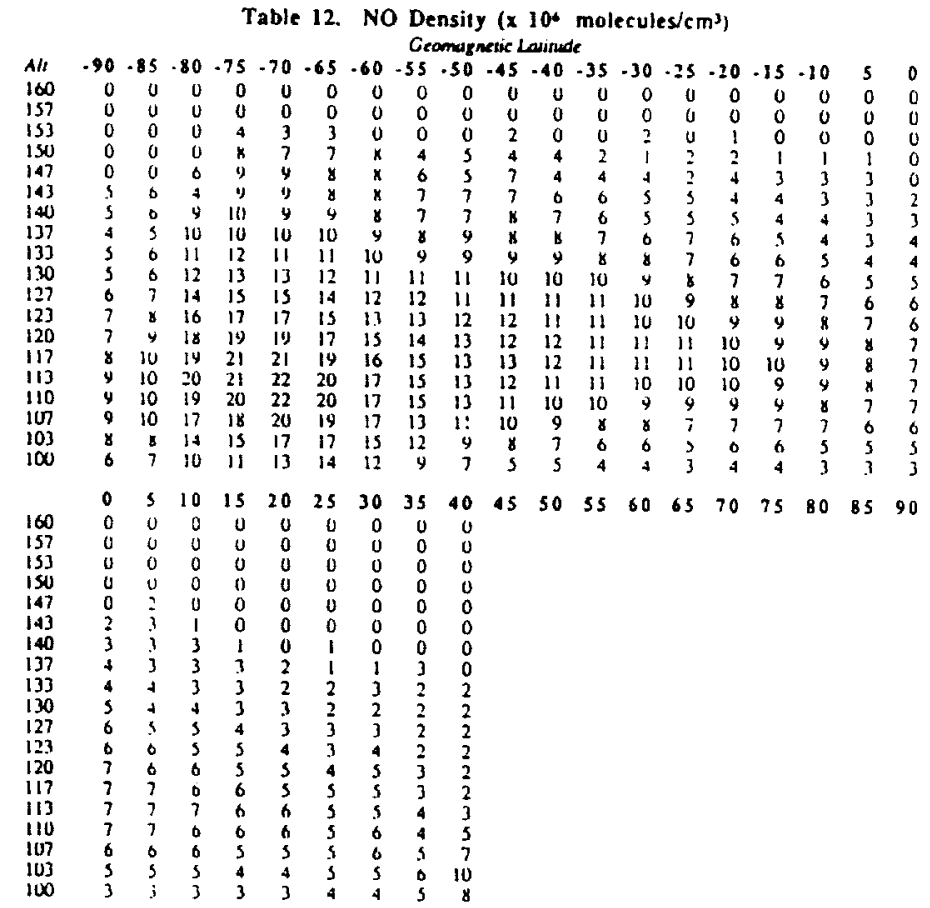

Table 12. Nitric oxide densily for the 1984-1985 southem summer solstice as a function of geonagnetic lattitude

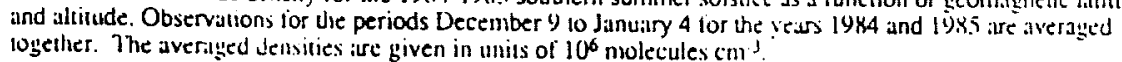

